\title{
Production Mining Based on the Results of Seismic Measurements at the "Zvečaj" Quarry Site - A Case Study
}

\author{
Melita SRPAK*, Darko PAVLOVIĆ, Igor KLOPOTAN, Željko KNOK
}

\begin{abstract}
During mass blasting, seismic effects occur that can significantly damage existing buildings near the blasting site, depending on the amount of explosives and the blasting distance itself. An additional problem during blasting is the facilities located in the critical zone of mining works - the problem of unpredictable behavior of the soil or rock in relation to the propagation of seismic waves. Based on the measurements performed on the example presented in this paper at the site of the quarry EP "Zvečaj" (minefield at the level of the second floor $K+163$ to $K+179$ ), the method is explained, how quality and well-conducted research can determine optimal amounts of explosives per ignition level. Based on the performed measurement procedures and processed data, measured and obtained results of values of soil oscillation velocities in the direction of populated areas caused by production blasting in the quarry EP "Zvečaj", it follows that the conducted mining activity, consequently, had no damage. Blasting significantly affects the environment, due to the emission of noise and seismic action, which is manifested in the form of oscillations and elastic deformations of the rock, which is an artificial earthquake in which the place of explosion is its epicenter.
\end{abstract}

Keywords: blasting; blasting effects; environment; noise; seismic effects of blasting; vibration

\section{INTRODUCTION}

In order to find out about the existence of mineral deposits, it is necessary to conduct research that boils down to the selection of a geographical area based on empirical data and geological knowledge. The main goal of such research is to determine the quality and quantity of raw material in the deposit. Total reserves of mineral resources are classified into certain categories according to the level of exploration of the deposit, the level of knowledge of the quality of the raw material and the parameters for determining the reserves [1, 2]. Exploration of solid mineral deposits according to Croatian regulations is determined by geological, geophysical, geochemical, hydrogeological and engineering-geological methods, all types of surface and underground exploration and surface and pit exploratory drilling $[3,4]$. When a mineral deposit is detected, seismic waves propagate through the surrounding area during mass blasting at quarries. As a result, certain seismic effects also occur, which can significantly damage existing buildings near the site of blasting [4, 5]. Experiences over many years of measurements have shown that the velocity, acceleration and displacement of particles in soil oscillations are the best parameters for assessing the damage caused to nearby buildings. The extent of the damage depends on the distance from the blasting site and the amount of explosives used [6]. At the same time, as the amount of explosives increases, the propagation space as well as the duration of the seismic disturbance increases. Therefore, it is necessary to perform preliminary research works and precise measurements of the seismic effects of test blasting in order to be able to determine the allowed quantities of explosives as reliably as possible. Often in practice, an additional problem when blasting are objects that are within the critical zone of mining operations, especially if they are objects that are under a certain degree of protection. The application of blasting as a technique in mining and construction is generally inseparable from the seismic action on both rock and soil, as well as on structures based on them. Oscillations initiated by blasting have a significant impact on the environment, and the effects vary from disturbing people to damage to buildings $[7,8]$. Damage to buildings is difficult to distinguish according to their occurrence, so even those caused by blasting cannot be clearly separated from damage caused in any other way. The degree of damage caused by this directly depends on the speed and frequency of vibrations of the building particles and the foundation soil, on the amount of explosives, the distance from the blasting site and the properties of the geological environment. Increasing the amount of explosives increases the duration and area of seismic disturbance, so the problem of determining the allowable amount of explosives is extremely sensitive and important, and therefore special attention should be paid to it. Considering demands of modern societies and primarily for technical and economic advantages, explosives for rock mass excavation have been widely used. Nevertheless, safety and particularly environmental concerns may arise in the use of these techniques; therefore, complex tools are needed to control these environmental effects, namely dust, noise, fly rock, and ground vibrations [9, 21]. In order for the drilling and blasting works at the "Zvečaj" quarry to take place without harmful consequences, it was necessary to perform field measurements of the soil oscillation speed. Measurements were performed during production (trial) blasting at the level of the second floor, i.e. $K+163$ to $K+197 \mathrm{~m}$ of the quarry, in order to determine the effects of seismic earthquakes on the surrounding settlements (buildings), or to determine the amount of explosive charge by ignition in order to avoid damage to nearby buildings near the quarry, [10].

\section{SEISMIC EFFECTS OF BLASTING}

The magnitude of seismic effects on the rock mass is determined by structural-textural features of rocks (stratification, cleavage, and joints), composition (mineral) and the bonding nature between individual grains [11]. The seismic effects of blasting include all forms of seismic action caused by mass blasting. The key criterion on the basis of which the endangerment of an individual object from seismic action is assessed is the speed of oscillations 
of soil particles or rocks caused by detonations of explosives in a mine well $[6,12]$. It is generally accepted that the speed of soil oscillations caused by blasting is related to the amount of explosive that detonates in each ignition interval, the distance of the observation site from the minefield and the characteristics of the basic tectonic structure of the rock mass. Defining the characteristics of rock masses in both geotechnical environments was carried out by classifying rock masses up to the level of determining the "Geological Strength Index (GSI)" as defined by Hoek [13], according to the "RMR" classification of Bieniawski [14] and part "Q" classification of Bartons [15]. Classification parameters were selected according to the direction in which, when measuring seismic effects, geophones were placed.

\subsection{Influence of Seismic Effects of Blasting on Nearby Buildings}

Seismic waves created by blasting cause mechanical movements of the soil, which are non-stationary periodic oscillations. When seismic waves reach a building, part of the ground oscillation energy is transferred to its foundations, so dynamic stresses occur in certain parts of the structure. To more accurately determine the allowable oscillation velocities, Karlheinz Arnold (Olofsson, 1990) takes into account the substrate on which the structure is based and the visible damage that occurs with stronger soil oscillations [16]. At a certain earthquake intensity, these stresses can exceed the ultimate strength of the material from which the building is built, which can cause permanent deformations $[16,17]$. Damage to buildings is very difficult to classify according to the method of its occurrence. Therefore, blasting is often attributed to damage to building structures that is actually caused by other causes, such as subsidence, uneven load, landslides, traffic, etc. Most of the vibrational energy appeared to be below $100 \mathrm{~Hz}$ and human perception of vibrations is usually examined in frequency ranges below $100 \mathrm{~Hz}$ [18]. Damage first occurs in the basement walls closest to the blasting site, and cracks can extend in all directions. The degree of damage to other buildings depends on the amount of explosive charge and the distance of the blasting site [19]. Damage will also occur at the points of weakening in the walls, such as openings, structural joints and old cracks due to subsidence, as well as contact joints with extended parts of the building [20].

\subsection{Criteria for Assessing Seismic Safety}

Many authors have dealt with the protection of buildings from seismic damage, and as a result of their research, a number of theoretical solutions and empirical formulas have emerged that define the mathematical relationship between soil vibration intensity and the amount of explosives [3, 20,21]. These formulas have one or more correction factors whose values are determined by field measurements or based on statistical data. In recent years, there has been a growing awareness in Croatia of the need for more detailed research into the seismic effects of blasting in the vicinity of buildings [17]. On the other hand, the allowed speeds of rock mass and soil oscillations are not standardized by domestic legal regulations, so in practice verified standards from abroad are used. The International Society for Rock Mechanics (ISRM) recommends the combined use of the German standard DIN 4150 and the American OSM (U.S. Office for Surface Mining), which treat soils and foundations [3, 12]. To calculate the peak ground oscillations at a certain distance on the terrain surface for normalized energy sources Wiss gave an expression similar to the USBM expression for the ratio of soil oscillation - distance - hammer impact energy, except that in the USBM expression the amount of explosive charge $C W$ was replaced by energy $W$ and the following expression is obtained [22]:

$P P V=K\left(\frac{D}{\sqrt{W}}\right)^{-n}$

The intensity of earthquakes caused by blasting is influenced by a number of factors, such as: physical and mechanical properties and geological structure of the rock through which seismic waves propagate, the amount and type of explosive charge, method and size of blasting and distance from blasting site. The intensity of oscillations is expressed in various measurands such as displacement, velocity, acceleration, frequency or energy of oscillations. Which of these quantities, and to what extent with the others, best represents the intensity of the seismic effect remains an open question, so different criteria are used to assess the seismic hazard. In Germany, the DIN 4150 standard classifies buildings by category and the corresponding permitted ground oscillation speeds depending on the frequency of oscillations. The display of the limit values of permissible ground oscillation speeds according to DIN standard 4150 is given in Tab. 1 [10].

Table 1 Limit soil oscillations according to DIN standard 4150

\begin{tabular}{|c|c|c|c|}
\hline Oscillation frequency & $<10 \mathrm{~Hz}$ & $10-50 \mathrm{~Hz}$ & $50-100 \mathrm{~Hz}$ \\
\hline $\begin{array}{c}\text { Building } \\
\text { category }\end{array}$ & \multicolumn{2}{|c|}{$\begin{array}{c}\text { Limit values of oscillation velocities } \\
\text { expressed in cm/s }\end{array}$} \\
\hline $\begin{array}{c}\text { 1. Offices and factory } \\
\text { buildings }\end{array}$ & 2.0 & $2.0-4.0$ & $4.0-5.0$ \\
\hline $\begin{array}{c}\text { 2. Residential buildings with } \\
\text { plastered walls }\end{array}$ & 0.5 & $0.5-1.5$ & $1.5-2.0$ \\
\hline $\begin{array}{c}\text { 3. Historic and other protected } \\
\text { buildings }\end{array}$ & 0.3 & $0.3-0.8$ & $0.8-1.0$ \\
\hline $\begin{array}{c}\text { For frequencies }>100 \mathrm{~Hz} \text { higher values of oscillation velocities can be } \\
\text { taken }\end{array}$ \\
\hline
\end{tabular}

The geological strength index is an assessment of the properties of rock masses, and is based on a visual assessment of the state of the rock mass structure and the state of rock mass discontinuities obtained by surface mines and borehole cores [23]. Therefore, we can conclude that the intensity of soil oscillation, the amount of explosive charge and the distance from the place of filling are expressions that have one or more correction factors whose values are determined by field measurements or statistics.

\section{MEASUREMENT OF SOIL OSCILLATION SPEED 3.1 Measuring Instruments and Equipment}

Soil oscillation velocities resulting from blasting can be measured in soil and construction, depending on the 
purpose and intent of the test. Specially designed portable seismographs are used to measure the speed of soil oscillations caused by blasting, which can be placed at any place where it is necessary to measure the resulting oscillations [16]. As a result of measurements in the foundation soil, oscillation values should be expected that have a general character and do not take into account the interaction of the foundation soil-structures. The oscillation velocity of the material particle in three mutually perpendicular planes is registered at the measuring points. Vibrations are captured by three-component geophones connected to a seismograph, each of which registers all three components of the ground oscillation velocity at the measurement site. Three-component geophones were placed at the Zvečaj quarry in such a way that:

- two geophones were placed in the horizontal plane, one in the direction of the detonation point (for registration of the longitudinal component of oscillations, marked with 1 in Fig. 1), the other perpendicular to the previous one (for registration of the transverse component of oscillations, marked with 2 in Fig. 1)

- the third geophone was located perpendicular to the horizontal plane (for the registration of the vertical component of oscillations, denoted by 3 in Fig. 1) $[8,16]$.

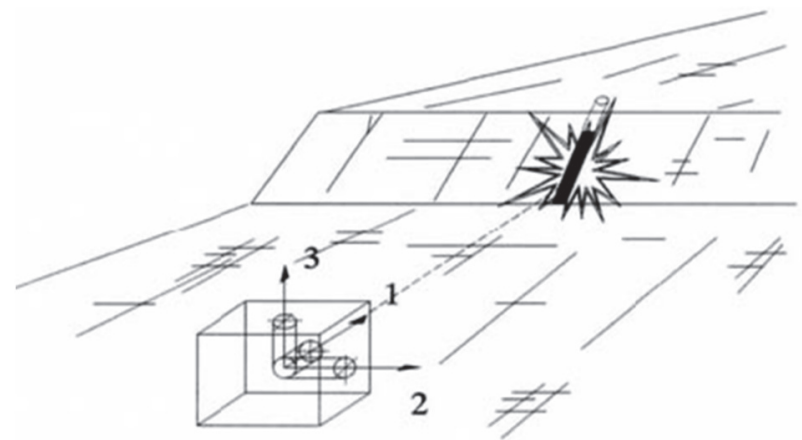

Figure 1 Measurement of oscillation speed with a three-component geophone

Instruments operating on the principle of a seismograph were constructed to measure the magnitude of soil oscillations. The speeds of soil oscillations resulting from blasting can be measured in the soil itself, the structure depending on the purpose of the test. The oscillation velocity of the material particle is registered at the measuring points. After the detonation, each geophone registers one irregular curve that is obtained on the recording (seismogram) of the resulting seismic disturbance (earthquake). After detonation, each geophone registers one irregular curve obtained on the recording (seismogram) of the resulting seismic disturbance (Tab. 2 and Fig. 2 and Fig. 2a) [23].

Table 2 Measurement of a seismogram in the "Zvečaj" (MO4)

\begin{tabular}{|l|c|c|c|c|}
\hline & Tran & Vert & Long & \\
\hline PPV & 4.65 & 3,10 & 3.59 & $\mathrm{~mm} / \mathrm{s}$ \\
\hline ZC Frequency & 57 & 51 & 47 & $\mathrm{~Hz}$ \\
\hline $\begin{array}{l}\text { Time from after } \\
\text { the recording }\end{array}$ & 0.219 & 0.213 & 0.224 & $\mathrm{~s}$ \\
\hline $\begin{array}{l}\text { Maximum } \\
\text { acceleration }\end{array}$ & 0.159 & 0.136 & 0.123 & $\mathrm{~g}$ \\
\hline $\begin{array}{l}\text { Maximum } \\
\text { displacement }\end{array}$ & 0.0144 & 0.0123 & 0.0159 & $\mathrm{~mm}$ \\
\hline Sensor check & Disabled & Disabled & Disabled & \\
\hline Frequency & - & - & - & $\mathrm{Hz}$ \\
\hline
\end{tabular}

Figure 2 Measurement of a seismogram in the "Zvečaj" quarry with a maximum vector sum of $15.7 \mathrm{~mm} / \mathrm{s}$ in $0.270 \mathrm{~s}$

DIN 4150

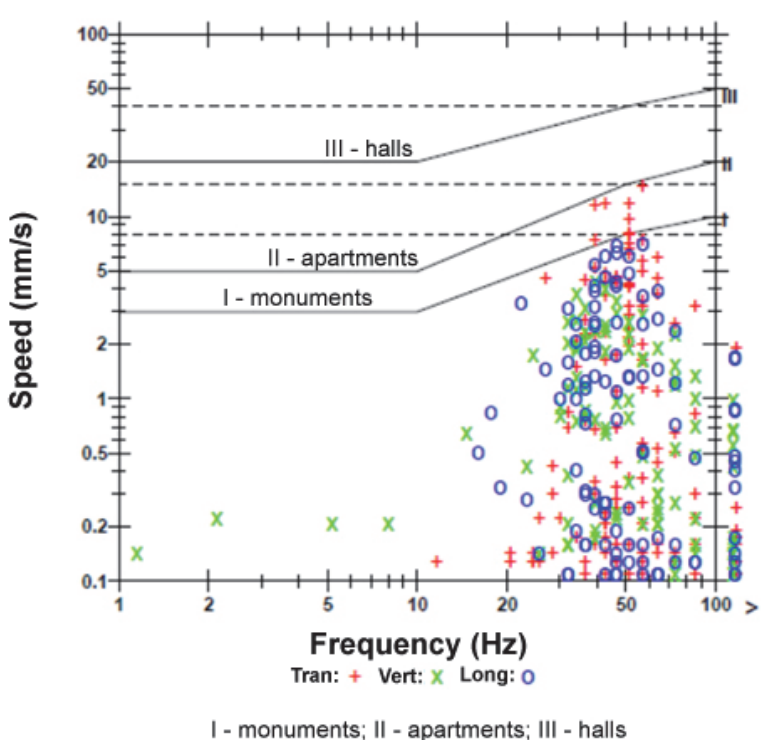

Figure 2a Results of measuring the oscillation velocities of the soil at the place of observation of $\mathrm{MO} 4$ during production blasting, in the direction of D. Zvečaj

Based on the obtained images, the velocities of individual oscillation components are calculated: $V_{\mathrm{L}}$ - velocity of the longitudinal oscillation component, $V_{\mathrm{T}}$ - velocity of the transverse oscillation component, $V_{\mathrm{V}}$ - velocity of the vertical oscillation component. The resulting ground oscillation velocity $\left(V_{\mathrm{R}}\right)$ is equal to the vector sum of the velocities of the individual oscillation components, which are taken from the seismogram at the moment of the greatest disturbance $(t)$ [10].

$V_{\mathrm{R}}=\sqrt{V_{\mathrm{T}}^{2}+V_{\mathrm{V}}^{2}+V_{\mathrm{L}}^{2}}$

For the needs of measurements during the development of the blasting project at the quarry "Zvečaj", digital seismic devices Instantel (MiniMate Plus) were used, which measure the speed, displacement, acceleration and the corresponding frequencies of soil oscillations and air shock wave.

\subsection{Measurement of Oscillations in the Field}

During production blasting at the "Zvečaj" quarry, soil oscillation velocities and an air shock wave were measured

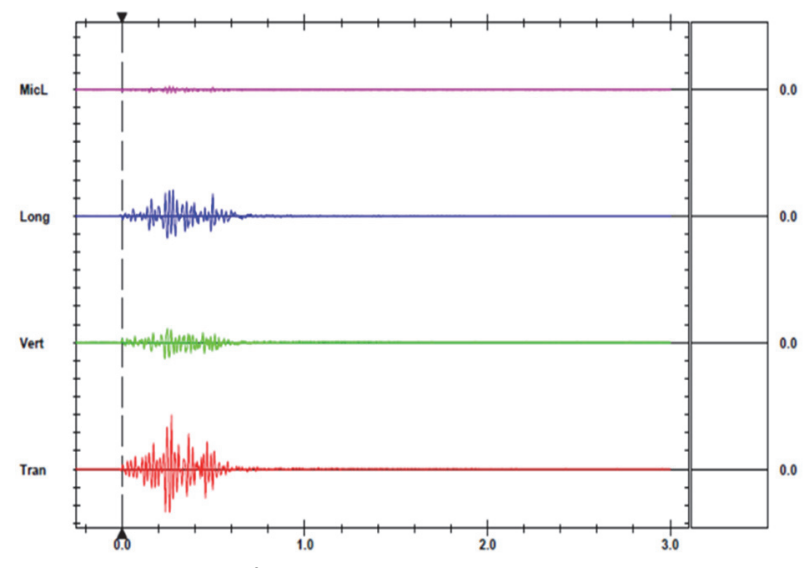


at a total of six observation points. A total of one minefield was fired at the level of the second floor of the terrain $(K+$ 163 to $K+179$ ). The distance of the observation site from the minefield was measured using GPS (Global Positioning System). By knowing the coordinates for two points, for the minefield (MP) and observation points (MO) the values of coordinates $Y, X$ and $Z$ are determined with an accuracy of up to $3.0 \mathrm{~m}$, and based on them the shortest distance in space between these two points $\left(R=D_{x y z}\right)$ according to the expression [10]:

$$
R=D_{x y z}=\sqrt{\left(Y_{1}-Y_{2}\right)^{2}+\left(X_{1}-X_{2}\right)^{2}+\left(Z_{1}-Z_{2}\right)^{2}}
$$

\section{DETERMINATION OF THE RADIUS OF THE VULNERABLE ZONE IN MINING}

The magnitude of the seismic effects depends on the amount of explosives, the distance from the blasting site, the method of blasting and the properties of the rock mass and soil.

Many researchers have published empirical expressions to determine the speed of oscillations and the maximum amount of explosive charge by degree of ignition.

One of the most commonly used terms for calculating the speed of oscillations is the expression Langefors [24]. Long-term observations confirmed the interdependence of the measured oscillation velocity and the stated parameters [25]. Langefors expressed the interrelationship with the expression:

$V_{\mathrm{R}}=K \times \sqrt{\frac{Q}{R^{1.5}}}$

that is, the stated dependence of the ground oscillation rate and other parameters according to the United States Bureau of Mines (USBM) is expressed by the following formula:

$V_{\mathrm{R}}=K \times\left[\frac{R}{\sqrt{Q}}\right]^{-1.6}$

where: $V_{\mathrm{R}}$ - resultant ground oscillation speed, $\mathrm{mm} / \mathrm{s} ; R$ distance of observation point from minefield, $\mathrm{m} ; Q$ amount of explosive charge detonating instantaneously, $(\mathrm{kg}) ; K$ - transmission coefficient and blasting method.

Based on the measured resultant oscillation velocities at two observation points, their distances from the minefield and the adopted permissible limit oscillation velocities according to the appropriate standard, the permissible explosive charge per ignition rate for certain distances from the minefield is calculated and graphically represented by $Q R$ diagram [1] (Fig. 3).

Knowing the maximum value of the resultant $V_{R}$ velocity obtained by measuring at the observation point MO, the amount of explosive charge $Q$ and the distance of the observation point $R$ from the minefield (MP) from the above expressions we calculate the transmission coefficient $K$. while the distances and markings of the measuring positions are shown in Tab. 3, [10].

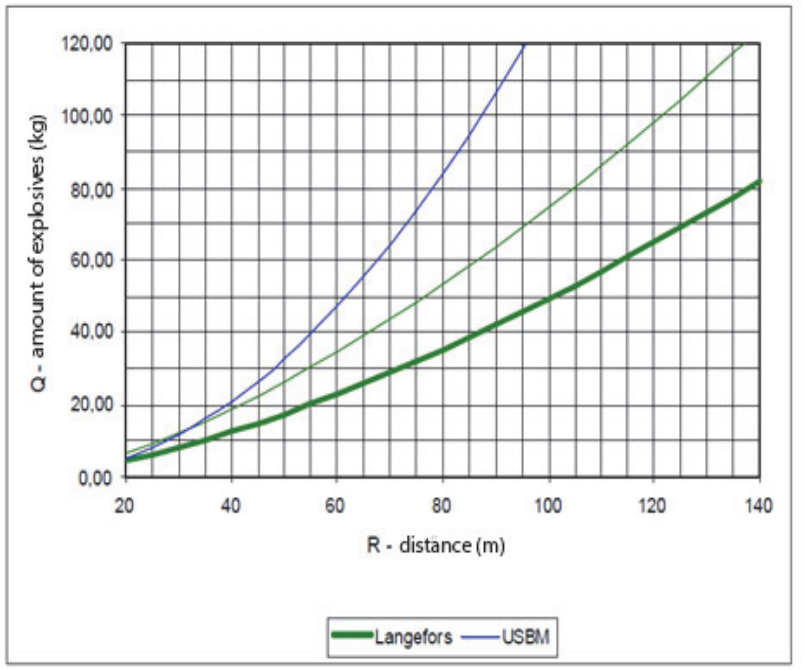

Figure 3 Permitted quantities of explosives for the speed limit

Table 3 The measured values of the resultant are the speed of soil oscillations at individual locations

\begin{tabular}{|c|c|c|c|c|c|}
\hline & MO 1 & MO 2 & MO 3 & MO 4 & MO 5 \\
\hline Position & Workshop & Stock & $\begin{array}{c}\text { Fudurić } \\
\text { D. } \\
\text { Zvečaj }\end{array}$ & $\begin{array}{c}\text { Fudurić } \\
\text { D. } \\
\text { Zvečaj }\end{array}$ & $\begin{array}{c}\text { Matković } \\
\text { N. } \\
\text { Brdo }\end{array}$ \\
\hline $\begin{array}{c}\text { Transmission } \\
\text { coefficient } \\
\text { according to } \\
\text { Langefors }\end{array}$ & - & 45.41 & 23.74 & 125.58 & 27.03 \\
\hline $\begin{array}{c}\text { Measurement } \\
\text { s } V_{\mathrm{r} / \text { cm/s }}\end{array}$ & 0.341 & 0.513 & 0.203 & 1.570 & 0.325 \\
\hline $\begin{array}{c}\text { Criteria } \\
\text { according to } \\
\text { freq. } \\
\text { spectrum / } \\
\text { cm/s - DIN } \\
4150\end{array}$ & 0.80 & 0.80 & 1.5 & 1.5 & 0.80 \\
\hline
\end{tabular}

Based on the measurements and measured values of soil oscillation velocities in the direction of the nearby settlements of Donji Zvečaj, Novo Brdo and Grganjica, or family houses (Fudurić, Mataković, Benić), caused by production blasting at the quarry EP "Zvečaj", minefield at the level of the second floor $K+163$ to $K+179$ ), it was determined that there was no damage from blasting. $0.5 \mathrm{~cm} / \mathrm{s}$, which corresponds to the speed of oscillations required to turn on the seismograph. The frequency spectrum and the measured transmission coefficients differ significantly for the direction of Zvečaj, or for Novo Brdo - quarry plant. The highest amount of transmission coefficient is calculated in the direction of MO 4 (Donji Zvečaj), $K=125$, which represents the direction of maximum energy transfer. Maximum explosion quantity of explosive charge in one interval on a minefield in level II eta was $80 \mathrm{~kg}(E g+E p)$ [23]. Langefors was chosen as the reference expression for the permissible value of the oscillation velocity of soil particles of $0.8 \mathrm{~cm} / \mathrm{s}$ (direction Novo Brdo - plant), and $1.5 \mathrm{~cm} / \mathrm{s}$ (direction Gornji Zvečaj) (DIN 4150). The analysis was performed in three groups with respect to the direction of propagation of seismic waves. The direction of Donji Zvečaj, especially MO 4, proved to be a critical direction. Drilling at the "Zvečaj" quarry was performed with self-propelled, hydraulic, percussion-rotary drills. As drilling was performed on a route that passes through terrain of different configurations, the drilling depth as well as the drilling geometry differed for each abutment or column 
foundation. Based on the "Study of deep drilling and mass blasting", blasting at the quarry "Zvečaj" was successfully performed. The obtained granulation of the mined rock mass meets the set requirements, except in the part of the minefield where 4 mine wells could not be filled due to their collapse. A sketch of a minefield with boreholes and a binding scheme in the Zvečaj quarry is shown in Fig. 4, while Fig. 5 shows a characteristic profile 1-1 through a well with a filling structure [10].

Sketch of a minefield with boreholes and a mooring scheme

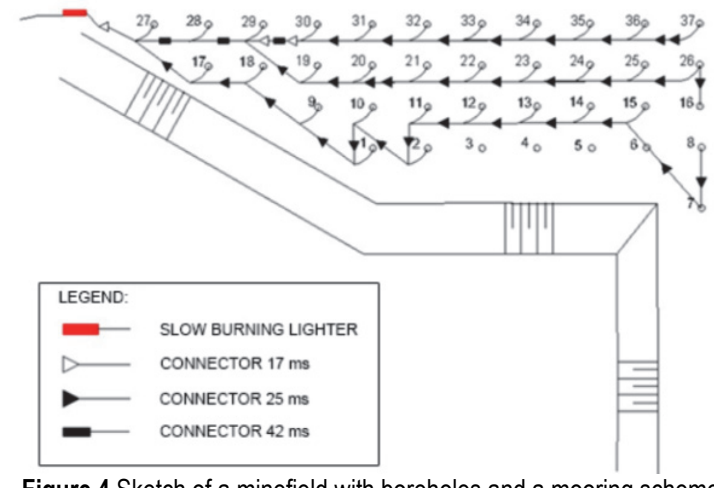

Figure 4 Sketch of a minefield with boreholes and a mooring scheme

Seismic waves created by blasting at the "Zvečaj" quarry caused mechanical ground movements that represent non-stationary periodic oscillations. When seismic waves reach a building, part of the energy of the soil oscillation is transferred to its foundations, so in some parts dynamic stresses occur. At a certain earthquake intensity, these stresses can exceed the ultimate strength of the material from which the building is built, which can cause permanent deformation. The blasting sounds that cause the greatest reactions of discomfort are the rattling of window panes, doors, unstable objects or sounds caused by blows from outside the building or from the roof. Sounds like this cause even more discomfort if they occur suddenly and unexpectedly.

CHARACTERISTIC PROFILE 1-1 THROUGH THE WELLBORE WITH FILLING CONSTRUCTION

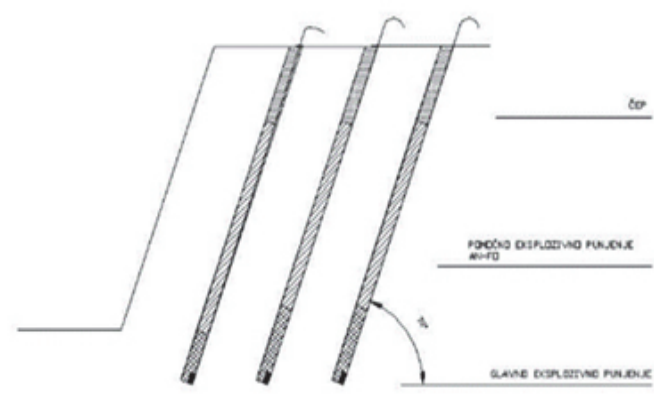

Figure 5 Characteristic profile 1-1 through the wellbore with filling construction

Based on research during the blasting at the "Zvečaj" quarry, the concerns of locals living nearby arose at times when they were exposed to the sound shock because it was related to potential damage to their homes rather than their bodies, and reactions diminished when they were not in own homes. When the sound shock occurred after a warning sign, aspects of discomfort were minimized, but some observed individuals erroneously concluded that the sound reaction of the apartment building indicated some kind of potential damage [5]. The localization of microseismic sources/acoustic emission in the rockmass structure can provide the basis for determining the potential areas of rockmass instability and rockburst in the underground mining [26]. Destress blasting is a rockburst control technique where highly stressed rock is blasted to reduce the local stress and stiffness of the rock, thereby reducing its burst proneness [27, 28]. Such sounds are much better accepted by the public, if people see the importance of such activities, either for them personally or for the general public.

\section{CONCLUSION}

Based on the measurements, a selected example from this paper at the location of the quarry EP "Zvečaj" shows the way (procedure) how quality and well-performed previous research can clearly determine the optimal quantities of explosives by ignition level (explosive consumption norm: $2265 \mathrm{~kg}, 8.022 \mathrm{~m}^{3}=0.280 \mathrm{~kg} / \mathrm{m}^{3}$ ), and whose detonation of seismic oscillations along the protected buildings remains within the permitted limits. In addition to the use of permissible amounts of explosives, it is always useful to apply known methods and techniques to reduce soil vibration. The allowable amount of explosive charge per ignition stage was performed according to Langefors, and according to the recommendation of the United States Bureau of Mines (USBM). Based on the performed measurements, measured and obtained results of the values of soil oscillation velocities in the direction of Donji Zvečaj, Novo Brdo and Grganjica, caused by production blasting at the location of the quarry EP "Zvečaj", minefield at the level of the second floor $(K+$ 163 to $K+179$ ), it can be concluded that the blasting activity did not result in any damage. The measured values at the measuring points meet the standards of permitted ground oscillation speeds and are within the permitted criteria for residential buildings.

According to DIN 4150 the obtained value of permissible soil oscillations for residential buildings is 0.8 $\mathrm{cm} / \mathrm{s}$ and $1.5 \mathrm{~cm} / \mathrm{s}$, and for the dominant frequencies of oscillations of particles measured at the location. Measured values indicate complex geological conditions and dispersion of seismic waves in relation to the direction of propagation. Finally, the measured values undoubtedly show that the frequency spectrum and measured coefficients transmissions differ for the direction of the settlement Zvečaj, in relation to the settlement Novo Brdo - quarry plant. It should be noted that the largest amount of the transmission coefficient was calculated in the direction MO 4 (Donji Zvečaj), $K=125$, (shown in Fig. 2 and Fig. 2a.), which is also the largest direction of energy transfer. It is important to conclude that the total duration of the detonation at the "Zvečaj" quarry should not be more than one second, due to the adverse impact of the seismic effect on residential buildings and the psychophysical reactions of the surrounding population. When the total oscillation time exceeds one second, the frequency of complaints and thus "reported" damages increases.

That is why instrumental observations of seismic oscillations in each blasting are an excellent way of control. However, if the project itself is undesirable, any project 
operation can be seen as undesirable, and the number of damage reports will be much higher than for a project that is well accepted or a project that is considered significant for the benefit of society.

\section{Acknowledgements}

This paper also describes the results of research being carried out within the project "Centar održivog razvoja"/"Center of sustainable development", co-financed by the European regional development fund and implemented within Operational Programme Competitiveness and Cohesion 2014-2020, based on the call "Investing in Organizational Reform and Infrastructure in the Research, Development and Innovation Sector".

\section{REFERENCES}

[1] Pavlović, D., Banovac, E., \& Vištica, N. (2018). Defining a composite index for measuring natural gas supply security The Croatian gas market case. Energy policy, 114, 30-38. https://doi.org/10.1016/j.enpol.2017.11.029

[2] Srpak, M. \& Pavlović, D. (2020). Sanacija zatvorenih i napuštenih eksploatacijskih polja mineralnih sirovina na prostoru Varaždinske županije. Naftaplin, 40(165),63-72.

[3] ISRM (1992). Suggested Method for Blast Vibration Monitoring. International Journal of Rock Mechanics and Mining Sciences, 29(2), 143-156.

[4] Srpak, M. \& Pavlović, D. (2020). Mogućnosti i potencijal geotermalnih voda u funkciji gospodarskog razvoja Varaždinske županije. Naftaplin, 40(163-164), 58-69.

[5] Strelec, S. et al. (1993). Utjecaj seizmičkih efekata miniranja na obližnje građevine (komparativna analiza). Rudarskogeološko-naftn izbornik, 5, 181-186.

[6] Božić, B. (2009). Miniranje II. Sveučilište u Zagrebu, Geotehnički fakultet, Varaždin.

[7] Krsnik, J. (1989). Miniranje. Sveučilište u Zagrebu, Rudarsko-geološko-naftni fakultet, Zagreb

[8] Mesec, J. et al (2012). Ovisnost intenziteta oscilacija tla prilikom miniranja o koeficijentu svojstava stijene i načina miniranja K, i koeficijentu prigušenja n. $2^{\text {nd }}$ Conference GEO-EXPO 2012, Proceedings, 599-606.

[9] Paneiro, G. \& Rafael, M. (2020). Artificial neural network with a cross-validation approach to blast-induced ground vibration propagation modeling. Underground Space. https://doi.org/10.1016/j.undsp.2020.03.002

[10] Strelec, S. et al. (2010). Studija seizmičkih efekata miniranja na lokaciji kamenoloma - EP "Zvečaj" SPP d.o.o. Varaždin

[11] Kuzmenko, A. A., Vorobev, V. D., Denisyuk, I. I., \& Dauetas, A. A. (1993). Seismic Effects of Blastingin Rock (1st.ed.). CRC. Press. https://doi.org/10.1201/9780203740002

[12] Mesec, J. (2009). Mineralne sirovine vrste i način dobivanja. Sveučilište u Zagrebu, Geotehnički fakultet, Varaždin

[13] Hoek, E. (1995). Strength of rock \& rock masses. ISRM News Journal, 2(2),4-17.

[14] Bieniawski, Z. T. (1989). Engineering rock mass classifications: A complete Manual for Engineers and Geologists in Mining, Civil and Petroleum Engineering. A Wiley - Interscience Publication.

[15] Barton, N. R., Lien, R., \& Lunde, J. (1974). Engineering classification of rock masses for the design of tunnel support. Rock Mechanics, 6(4), 189-236. https://doi.org/10.1007/BF01239496

[16] Olofsson, S. O. (2002). Applied explosives technology for construction and mining. Ärla, Sweden: APPLEX AB

[17] Siskind D. E, Stagg, M S, Kopp, J W, \& Dowding, C H. (1980). Structure response and damage produced by ground vibration from surface mine blasting. United States.
[18] Sica, G., Peris, E., Woodcock, J. S., Moorhouse A. T., \& Waddington, D. C. (2014). Design of measurement methodology for the evaluation of human exposure to vibration in residential environments. Science of the Total Environment, 482-483, 461-471. https://doi.org/10.1016/j.scitotenv.2013.07.006

[19] Božić, B. (1989). Miniranje u rudarstvu, graditeljstvu I geotehnici. Sveučilište u Zagrebu, Geotehnički fakultet, Varaždin

[20] Beltran, F., Yañez-Gonzalez, A., \& Crespo, M. J. (2020). Indirect determination of shear wave velocity in slow formations using full-wave sonic logging technique. Journal of Rock Mechanics and Geotechnical Engineering, 12(6), 1226-1233. https://doi.org/10.1016/j.jmge.2020.05.009

[21] Paneiro, G., Durão, F.O., Costa e Silva, M. et al. (2020). Neural network approach based on a bilevel optimization for the prediction of underground blast-induced ground vibration amplitudes. Neural Computing and Applications, 32, 5975-5987. https://doi.org/10.1007/s00521-019-04083-2

[22] Wiss, J. F. (1981). Construction vibration: State-of-the Art. America Society of Civil ASCE. Journal of Geotechnical Engineering Division, 107(2),167-181.

[23] Marinos, V., Marinos, P., \& Hoek, E. (2005). The geological strength index: applications and limitations. Bulletin of Engineering Geology and the Environment, 64, 55-65. https://doi.org/10.1007/s10064-004-0270-5

[24] Langefors, U., Kihlstrom, B., \& Westerberg, H. (1957). Ground Vibrations in Blasting. Water Power.

[25] Strelec, S., Božić, B., \& Gazdek, M. (2003). Different Evaluation Criteria of Permissible Explosive Quantity, Proceedings of EFEE 2nd World Conference on Explosives and Blasting Technique, Prague, 119-126.

[26] Dong L., Zou W., Li X., Shu W., \& Wang, Z. (2019). Collaborative localization method using analytical and iterative solutions for microseismic/acoustic emissions ources in the rockmass structure for underground mining. Engineering Fracture Mechanics, 210, 95-112. https://doi.org/10.1016/j.engfracmech.2018.01.032

[27] Isaac, V., Hani, M., Damodara, R. C., \& Mike, Y. (2020). Large-scale destress blasting for seismicity control in hard rock mines: A case study. Internation Journal of Mining Science and Technology, 30(2), 141-149. https://doi.org/10.1016/j.jimst.2020.01.005

[28] Vennes, I. \& Mitri, H. S. (2017). Geomechanical effects of stress shadow created by large-scale destress blasting. Journal of Rock Mechanics and Geotechnical Engineering, 9(6), 1085-1093. https://doi.org/10.1016/j.jrmge.2017.09.004

\section{Contact information:}

Melita SRPAK, univ. spec. oecing., mag. agr.

(Corresponding author)

Varaždin County, Institute for Physical Planning,

Mali Plac 1a, 42000 Varaždin, Croatia

E-mail: melita.srpak@gmail.com

Darko PAVLOVIĆ, Asst. Prof., PhD

Gas Transmission System Operator (PLINACRO L.T.D.),

Savska cesta 88a, 10000 Zagreb, Croatia

E-mail: darko.pavlovic@plinacro.hr

Igor KLOPOTAN, Asst. Prof., PhD

Polytechnic of Međimurje in Čakovec

Bana Josipa Jelačića 22a, 40000 Čakovec, Croatia

E-mail: igor. klopotan@mev.hr

Željko KNOK, mag. ing

Polytechnic of Međimurje in Čakovec

Bana Josipa Jelačića 22a, 40000 Čakovec, Croatia

E-mail: z.knok@mev.hr 